\title{
Campaigning in a Changing Information Environment: The Anti-war and Peace Movement in Britain
}

Link to publication record in Manchester Research Explorer

\section{Citation for published version (APA):}

Gillan, K., Pickerill, J., Webster, F., Hunsinger, J. (Ed.), Klastrup, L. (Ed.), \& Allen, M. (Ed.) (2010). Campaigning in a Changing Information Environment: The Anti-war and Peace Movement in Britain. In International Handbook of Internet Research (pp. 217-231). Springer Nature. http://www.springer.com/computer/general+issues/book/978-14020-9788-1

\section{Published in:}

International Handbook of Internet Research

\section{Citing this paper}

Please note that where the full-text provided on Manchester Research Explorer is the Author Accepted Manuscript or Proof version this may differ from the final Published version. If citing, it is advised that you check and use the publisher's definitive version.

\section{General rights}

Copyright and moral rights for the publications made accessible in the Research Explorer are retained by the authors and/or other copyright owners and it is a condition of accessing publications that users recognise and abide by the legal requirements associated with these rights.

\section{Takedown policy}

If you believe that this document breaches copyright please refer to the University of Manchester's Takedown Procedures [http://man.ac.uk/04Y6Bo] or contact uml.scholarlycommunications@manchester.ac.uk providing relevant details, so we can investigate your claim.

\section{OPEN ACCESS}




\title{
Campaigning in a Changing Information Environment: the Anti-War and Peace Movement in Britain"
}

\author{
Kevin Gillan, Jenny Pickerill and Frank Webster ${ }^{1}$
}

\author{
This is an authors' pre-print of a book chapter appearing as: Gillan, K., Pickerill, J., \& Webster, F. \\ (2010) 'Campaigning in a Changing Information Environment: The Anti-war and Peace Movement in \\ Britain.' In J. Hunsinger, L. Klastrup, \& M. Allen (Eds.), International Handbook of Internet Research \\ (pp. 217-231). Dordrecht: Springer. The book is available from: \\ http://www.springer.com/computer/general+issues/book/978-1-4020-9788-1.
}

\section{Introduction: the mediation of war}

The experience of war has been in decline for some years. We are left with what John Mueller (2005) appositely calls 'the remnants of war', with decreasing numbers of people victims of armed conflict around the world and obligatory national service much diminished for most young men (Human Security Report 2005). In spite of the break up of Yugoslavia in the 1990s, the horrors of Rwanda and the Iraq occupation, most people live far safer lives than their parents and grandparents. The twentieth century was the bloodiest in human history, but mass killing is on the wane. Despite this, huge numbers of people feel anxious, even fearful, that we live in especially dangerous times. Opinion polls record large segments of the populations in the United States and Western Europe putting the risk of war ahead of other public concerns (http://www.angus-reid.com).

Let us underscore this point. Eric Hobsbawm (1994) tells us that the period 1914-45 may aptly be termed the 'age of catastrophe' since it was characterised by virtually continuous fighting between - and within - fascist, communist and capitalist nations. In many parts of the world,

\footnotetext{
* Contribution to Jeremy Husinger, Matthew Allen and Lisbeth Klastrup (eds), International Handbook of Internet Research (Springer)

${ }^{1}$ Kevin Gillan is Research Assistant at City University, Jenny Pickerill is Lecturer in Human Geography at Leicester University, and Frank Webster is Professor of Sociology, City University. The authors would like to thank the ESRC (Economic and Social Research Council) for support of the research included in this article (RES 228-25-0060).
} 
young men aged eighteen and over were called to military service as a matter of course, to engage in killing. For lengthy periods nations fought à outrance, as total war enveloped them. Describing a 'war of annihilation' in the East and a 'brutal peace' that followed Mark Mazower (1998, p.216) reminds us of the enormous scale of death and dislocation in Europe between 1939 and 1948: he estimates that 40 million people were killed and many more than that forced from their homes (p.222). Large scale conflict continued into the 1980s in wars of national liberation and superpower proxy wars: Algeria, Korea, Congo, Vietnam, Cambodia, Guatemala, Nicaragua....

Much of this is within living memory. It stands in marked contrast to the high levels of anxiety and fear expressed about the current situation across age groups. This is not to discount the threat of nuclear proliferation, nor to trivialise the suffering of those in Iraq, nor to ignore the atrocities taking place in Darfur. But it is to insist that war, and the threat of war, has diminished for most inhabitants of the world over the past two decades.

So how is it that there are such anxieties expressed about war today in spite of the improvements as regards peace? A vital factor has to be the massively increased media coverage. We live now at a time in which we are presented with an unceasing diet of news and comment on the risks of war, of the dangers of terrorism, of reportage of unrest from many parts of the world. This comes to us round the clock, with rolling news, and cable and satellite services ensuring pervasive coverage. It is produced and updated rapidly, it is globalised, and it is often in 'real time'. War is dramatic, unquestionably important, a matter of life and death and it can draw literally thousands of journalists to report on it.

There is no direct causal relation between media and fear of war. We prefer to conceive of there being more resources now being available to people who may use these to reflect on a greater range and variety of information about conflict than their forebears. For a good many, perhaps most, these resources generate anxiety and fear. This is a remarkable phenomenon: while our parents and grandparents frequently had direct experience of conflict, today we have much greater knowledge of war, but chiefly at a distance (Seaton 2005). We are safer from war than ever, yet we witness it, often in appalling detail, as spectators (Ignatieff 2000). The astonishing informational output lets us know far more about conflict, about campaigns' development and attendant risks, about the consequences of bombing and military clashes, than the sailor mobilised to the Atlantic convoys or the $6^{\text {th }}$ Army infantryman encircled at Stalingrad could have imagined. The sailor and infantryman knew well enough what it was to meet the enemy and feel the bitter 
cold of the Russian winter, but today's media-rich viewer can get instantaneous coverage from many spheres of battle, watch reporters communicating from satellite video phones, and then have this digested for its strategic significance by politicians and experts. It is these greater informational resources that enable what Anthony Giddens (1994) calls the 'intensified reflexivity' (p.24) of life today. Heightened consciousness of war and the threat of war are elements of this.

\section{The Control Paradigm}

We would highlight the enormous growth and extension of media today. On one level this is simply a matter of drawing attention to the character of media - lots more channels, 24/7 services, transnational news services such as $\mathrm{CNN}$ and BBC World. But what is understood by media must also come to terms with the PC, the World Wide Web, e-mail, blogs and cognate technologies. Even established media now require reconceptualisation: the Guardian newspaper sells less than 400,000 hard copies daily, but its website, Guardian Unlimited, achieved between three and four million electronic hits each day through 2006; the Times newspaper makes around 600,000 sales per day, yet the Times Online website gets three times that many hits; the BBC News broadcast at 10 p.m. commands audiences of about 4.5 million, while its web site is accessed 20 million times a day (http://www.alexa.com). The Internet is the major phenomenon here and it already plays an important role in the ways people become informed about what is happening in their world.

It is not surprising that governments and military forces, being aware that citizens learn about war through media, pay careful attention to managing information. Conscious that public opinion matters enormously when it comes to war, politicians and commanders assiduously practice 'perception management' (Taylor 1992). They want, as far as they can manage, to have publics receive news and reports that justify their conduct. From this follows much documented practices of 'PsychOps', chaperoning journalists, and photo-opportunity events designed by central command.

Those who wage war, yet who seek public legitimacy, endeavour to put the most favourable gloss on their conduct and policies. Media researchers have too readily moved from recognising this aspiration to working with a control model of information about war that presupposes military and government are able to get away with it. Researchers in this mode might undertake, for example, content analysis of newspaper and television reports, demonstrate that there are patterns to reportage, and conclude that most of these prioritised government and military spokespeople. 
The conclusion is easily reached that media are disproportionately influenced by military and government sources.

The most telling criticism of the control paradigm is that it is outmoded. Instead of control, one might better conceive the information environment of war and conflict nowadays as chaotic, certainly more confused and ambiguous than might have been possible even a generation ago (McNair 2006). Amongst the reasons for this is the resistance of many journalists. It is exceedingly hard for the military and governments to control a diverse group of often hundreds of correspondents who set out from the presumption that all sources are trying to manipulate them (Tumber and Webster 2006). Not only this, journalists are usually equipped with satellite video phones and laptops that allow them to report more or less immediately with little entourage and without being reliant on official sources, at the same time as they can access huge repositories of alternative information from the internet. Furthermore, the development of satellite and cable television, and transitional news services from BBC World to Al Jazeera, means that audiences have much more differentiated information sources than were possible just a few years ago (Calhoun 2004). The increased availability of the internet to ordinary citizens, bringing along blogs, e-mails, electronic versions of newspapers and periodicals, video clips and web sites, means that any idea of information control being readily achievable from conflict zones must be jettisoned. It is striven for, but the information domain is so febrile, extensive and open that control is at best an aspiration.

It is necessary to conceive of a much more expanded and differentiated information environment than hitherto. Publics are receiving their information on war mediated, but this is a mediation that is now considerably more ambiguous. It comes quicker than previous forms, it is less predictable, much denser and more diverse than before. To say this is not to suggest there is a full pluralism operating in the media realm, but it is to insist that space has opened up in a vastly expanded realm. Scholars need to acknowledge that we are 'engaged in the first war in history... in an era of e-mails, blogs, cell phones, blackberrys, instant messaging, digital cameras, a global internet with no inhibitions, hand-held video cameras, talk radio, 24-hour news broadcasts, satellite television. There's never been a war fought in this environment before' (Rumsfeld 2006). This does not deny the mediation of war, but it complicates it to a remarkable degree. Those who wage war have acknowledged the change (Department of Defense 2003). British Prime Minister Blair (2007) appreciates that 'twenty-five years ago, media reports came back from the Falklands [during the 1981-82 war with Argentina] irregularly, heavily controlled', but nowadays internet 
sites allow 'straight into the living room... gruesome images (that are) bypassing the official accounts'. As such, this 'transforms the context within which the military, politics and public opinion interact'. It is time media researchers also recognized this.

\section{An Alternative Information Environment?}

When it comes to the mediation of war and the threat of war the information environment might be conceived as one of symbolic struggles between various agencies that compete for time, for news agendas, and for interpretations of events. A significant set of players in these symbolic struggles are the anti-war and peace movements. They strive to ensure that their perspective gets access to media in various ways, from organizing enormous demonstrations that may be coordinated across the world and be compellingly newsworthy, as in February $15^{\text {th }} 2003$ where so many people took to the streets of major cities that a New York Times writer was moved to describe the action as 'the second superpower' (Tylor 2003), to presenting journalists with briefing papers setting out well argued and coherent opposition to those who wage war. They also adopt a panoply of new media - e-mail communications, list serves, web sites, discussion groups... - in the struggle to ensure that their views get a platform.

We return to the relation of the anti-war and peace movements with established media below, but we would stress here that the changed and changing information environment means that we need to think beyond a settled media in which movements are reported upon. The changed information environment has allowed the anti-war and peace movements to create their own media, even to establish what might be considered an alternative information environment. Robin Beste, web maintainer and office manager of Stop the War Coalition (StWC), the main coalition in the UK, described this to us. Like several of his co-activists, Beste feels that the anti-war movements receive poor coverage in more mainstream media. He complains that 'there are fewer and fewer oppositional voices available in mainstream media; everything seems to be filtered through government and establishment journalists'. Beste regards StWC's Newsletter (for which he is responsible) that goes out to 20,000 subscribers via a listserve as an important element of an alternative information network for campaigners. It appears fortnightly or so, though in periods of intense activity more frequently, and it offers a digest of key issues, comment on topical matters and hyperlink connections to other sources of information. Given that Beste 'think(s) some of the previous sources have deteriorated badly', it is little surprise to hear him declare that 'we're continually saying it, thank god for the internet'. One suspects that this sentiment is shared by 
Tom Feeley, the producer of the daily electronic newsletter - Information Clearing House - that circulates from Southern California to subscribers across the world offering 'News you won't find on CNN or FoxNews', the site of which got around 200,000 daily hits through 2006 (http://www.alexa.com).

Robin Beste told us that 'it's very difficult to get mainstream media to relate to us at all, but I don't care anymore. These people who get livid, "look we have this demonstration, we have all these people, there's not anything in the paper", I don't expect anything from them (the media) anymore. So if we get something that's just a bonus. And the reason why it doesn't trouble me anymore is because we do definitely have our own networks'. His working day begins around 6 a.m. when he does an online review of 'a whole series of websites that I always look at in terms of information' which he then uses to update StWC's web site. He is attuned to what Lance Bennett (2003) calls 'epistemic networks' far and wide which he raids to ensure that information supportive of StWC's priorities is available on its web site. This is oppositional information available to anyone checking StWC's web site.

Beste reminded us that this alternative network allows speedy and effective challenges to mainstream accounts. He was being interviewed a few weeks after the arrest in August 2006 of over twenty Muslims in the UK on suspicion of planning terrorist attacks on aircraft by smuggling bomb making equipment aboard. He pointed out that there has been widespread media coverage of the arrests, but little criticism of the action. Beste suggested that this could be challenged through the internet resources of StWC: 'there's a whole climate of truth mainstream media has created that we feel we have to counter and ... put it on our website. Our treasurer has got a particular interest in the terror plots that we've had... Now he has put together a little pamphlet which actually in a very non political (way), just "these are the facts of what it was and this is what the result of it was". You know you get this massive media thing, you get (arrests of suspects)...they're often charged, they go to court, nearly every case so far is thrown out, but when it's thrown out the media doesn't... So initially there's this massive thing like we've got now. Now that type of thing, you respond to those things via the internet and you find the best information is via the internet. From the States there's an article which we got... by an American who found a scientist who' $d$ actually looked at what the ...plotters would have to do to actually...' that raised serious doubts about the technical possibilities of those arrested putting together in-flight the bomb-making constituents that they were alleged to have smuggled aboard. 


\section{Mediated Politics}

Today's enlarged information domain provides opportunities for dissident views, but it has grown while a traditional informational source has diminished in importance. There has been a perceived decline especially in the public meeting where politicians and activists would come together with interested citizens and discuss matters of the moment. Public meetings still play a vital role in campaigning, but Robin Beste recalls a time when there were many more such occasions where interested parties could be exposed to alternative perspectives. Beste remembers that, a few years back, 'I would go to a public meeting and it would be brilliant speakers who would give you a context ... You could go to meetings all the time, the whole range... but a lot of that's gone'. He reminisced about an older generation of activists who prioritised public meetings and he still recognises the value of this method of getting people involved. But he regards the internet now as key to informing and organising. This is in accord with Manuel Castells (1998) who coined the term 'informational politics' to emphasise that parties and activists must be committed to new media or condemned to 'political marginality' (p.312). In so far as most people are conscious of war, nowadays this comes through media. Opponents of war must compete in that domain.

\section{Information Circuits}

All the significant anti-war and peace movements have produced web sites that, relatively cheap to set up and maintain, were unknown a decade ago (Pickerill, 2003). The web sites contain varying amounts and qualities of information, but typically provide a statement of principles, news and comment as well as links to cognate organisations. They are a first port of call for those wanting to know more, often by-passing secondary information sources such as newspapers. The sites generally offer facilities that allow readers to sign up to a list serve, so that they may receive e-mail messages that will keep them up to date direct from the group.

So elements of an alternative information network are in place, but there are complex connections with established media. To better appreciate the current information environment we need to take cognisance of the information circuits that flow between different media, groups and actors. There are several sorts of circuitry that might be distinguished.

1. Information flows from established media to the anti-war and peace movements. Interest in a subject makes people eager to seek out information. Anti-war and peace campaigners 
are hungry for news and comment about conflict and seek it out in a range of media, though quality newspapers on the liberal end of the spectrum, such as the Guardian and the anti-Iraq War Independent, are disproportionately read. However, this is not simply a matter of activists reading a particular newspaper. StWC's web site, for example, presents many articles taken from mainstream as well as oppositional periodicals, allowing those who wish to access particular pieces - commentaries, features, news items - via hyperlinks from the StWC web site. Heavily used in this respect is the Guardian newspaper's website, Guardian Unlimited, which allows free use of materials. This flow of information to the anti-war and peace sites extends to collating government reports and publications in documents and articles authored by activists. Milan Rai of Justice Not Vengeance produces briefing papers that he distributes to a listmail of around three thousand subscribers. 'All the sources', he explains, 'are completely mainstream', being 'newspapers or government reports or reports from establishment bodies like Chatham House'.

2. Information flows from anti-war and peace movement activists to mainstream media. The established media report on the anti-war and peace movements, for example when it stages a demonstration or rally. In such circumstances the movement adopts various tactics that help get its message across into the mainstream, from cultivating contacts with sympathetic journalists to ensuring high visibility by, for instance, designing eyecatching displays and memorable slogans. For instance, a national demonstration was held in London on August $5^{\text {th }} 2006$ to protest against the Israeli invasion of Lebanon. StWC had organised the demonstration around the theme of 'Unconditional Ceasefire Now' and to maximize effect it urged members and sympathisers to turn out in large numbers, promoted the support it had from distinguished figures, and urged demonstrators to bring along children's shoes to deposit as a symbol of innocent lives being taken by Israel actions. The amount of influence anti-war and peace protesters have is limited, not least because they lack resources as well expertise in public relations. Lindsey German, convenor of StWC, contrasted the 'very, very slick PR operation' of three wealthy former employees of National Westminster Bank who were facing extradition to America on charges of financial malfeasance during the summer of 2006 with StWC's much more modest endeavours. She admitted that 'it's very hard to punch your weight in that area unless you've got high flying professionals'. Nevertheless, in the current period the fact that two national newspapers (the Daily Mirror and the Independent) editorially support the anti-war and peace movements does mean that 
considerable amounts of sympathetic coverage is ensured. Thus on the day of the August $5^{\text {th }} 2006$ demonstration the Independent newspaper supported it with a front page full of mug shot photographs that featured esteemed individuals wearing tee-shirts proclaiming 'Unconditional Ceasefire Now'. Finally, one might note that several anti-war and peace supporters figure regularly in some of the mainstream media - for example, John Pilger, Robert Fisk, Andrew Murray and Gary Younge. These congregate in the pages of the Guardian, Mirror and Independent, but they are generally then put onto web sites where they can be readily accessed by anti-war and peace campaigners.

3. Web Sites, Blogs and Interactivity. These areas of the internet readily service the alternative information networks of the anti-war and peace movements, but some observations on their relationships to established media might be made. As a preliminary, we might remind ourselves of the novelty of cyberspace and the blogosphere: just a decade ago web sites were almost unknown, e-mail just taking off, discussion groups and chat rooms little used. Now web sites are prevalent in the anti-war and peace movements, and these often include features that enable readers some interactivity. Blogging has grown rapidly, especially since 2004, so much so that a Harris poll in Britain (Guardian, $16^{\text {th }}$ October 2006) reported that $40 \%$ of internet users (which amount to about $70 \%$ of the population) read a blog. The PEW (Lenhart and Fox 2006, p.20) organisation estimates that $90 \%$ of bloggers allow readers to respond, hence integrating interactivity into the process. These developments, still inchoate, merit comment in terms of traditional media not least because many journalists are informationally insatiable and avidly seek out sources. As such, we come across materials from web sites finding their way into mainstream media. For instance, when Tony Blair admitted on a television talk show that he prayed and would be answerable to God for his Iraq policy, the mother of a soldier killed in that country, Pauline Hickey, wrote a commentary on the StWC web site. Later this piece was reprinted in the Guardian newspaper (March $2^{\text {nd }}$ 2006). Such a direct relationship is rare, but it is clear that journalists keep a close eye on the internet and its traffic. As such they are amongst the more avid readers of blogs (and many journalists, especially the commentariat, maintain their own blogs) and this can influence what they write. For instance, during the summer of 2006 when Muslims were arrested in Britain on terrorism charges, Polly Toynbee noted in her Guardian column that 'the Internet hummed with theories that this was all a plot to deflect attention from Lebanon' (15 August 2006). Regular media such as The Times and Guardian now also offer reviews and comments on web sites and blogs. In addition, some have web sites that allow 
readers to contribute to discussion. For example, the Comment is Free section of Guardian Unlimited is interactive, featuring articles from the newspaper along with a range of blogs from an extensive list of contributors that are accompanied by often lengthy reader comment; 'The aim is to host an open-ended space for debate, dispute, argument and agreement and to invite users to comment on everything they read' (http://commentisfree.guardian.co.uk/). Even the BBC, Britain's most used web site, enables readers to comment on news items. From a different angle, some blogs can be a form of journalism that is itself newsworthy. For instance, blogs from Baghdad have provided insight into conditions and experiences where journalists cannot easily go. Nor surprisingly, these sites are frequently visited, reported on in traditional media and on occasion produced in book format (Salam Pax 2003; Riverbend 2005).

The information environment now instances significant traffic between and across traditional media and the anti-war and peace movements. There is appropriation from the mainstream media, contributions made more or less directly to that media, and, with new media especially, possibilities of amplification, challenge and discussion through interactive features and the growth of the blogosphere. While a good deal of these developments enable an autonomous information network to be constructed, it is also clear that the anti-war and peace movements connect with established media in significant ways. To emphasise, none of this ought to be interpreted as suggesting that we now have a plurality of equal voices - official spokespeople still get the lion's share of attention and it is rare for the anti-war and peace movement actors to set agendas for consideration. It is simply that the information environment is now considerably expanded and possessed of more possibilities of participation than traditional media, and scholars need to acknowledge this fact (Coleman 2005).

\section{Moving beyond Mediation}

We have emphasised that nowadays war is a mediated experience for most people, and that symbolic struggles are a striking feature of today's Information Wars (Tumber and Webster 2007). But mediation is by no means all there is about war nor is it the whole story of the antiwar and peace movements in Britain. War is about killing and defeating enemies and the anti-war and peace movements want to stop this happening. Exposing people to anti-war and peace perspectives is necessary to effect this, but it is not sufficient. The New York Times, in a recent editorial (August $31^{\text {st }}$ 2006), underscored this when it observes that, while a 'majority of Americans now say they oppose the (Iraq) war', it is difficult to find this publicly expressed in 
marches and vigils. 'Bloggers say there is an anti-war movement online', says the New York Times, but 'it takes crowds to get America's attention'. It is cheap to set up a web site and it takes little effort to sign an e-mail petition, so not surprisingly electronic campaigns that remain in the realm of the virtual are of limited consequence (Chadwick 2006, p.121). It is because this is so that Robin Beste criticizes 'people who see it [the internet] as the end in itself... There are lots of people actually campaigning who submerge themselves into it completely... I know individuals whose whole life is producing their blogs, but they're not related in any way to anything that goes on, on the ground'.

Acknowledgement of the importance of mediation to contemporary warfare should not lead us into the trap of mediacentrism. In Britain most anti-war and peace campaigners endeavour not just to change consciousnesses, but also to change policies by mobilising opposition to war. It will use new media more or less adroitly, for example in terms of coordinating members more effectively or marshalling sympathisers more speedily. It may do this in ways that use new media intensively and with ingenuity, as for instance with the Faslane 365 campaign against Trident nuclear missiles that is coordinating a year's series of autonomous peaceful protests of different groups at the Scottish missile site (http://www.faslane365.org/). But the context is one of stopping or preventing war, so more than symbols are involved. David Gee from the Society of Friends, for example, explains that 'if there is an attack on Iraq or on Iran... we instantly have the infrastructure there to mobilise the entire Quaker network, so there'll be somebody in every meeting, in all those 400 odd meetings, that will have access to the internet, at least one person I would have thought, who can quickly look, and it'll be on the home page of the Quaker site, look at the Peace Exchange (web site)... There'll be a whole list of things you can do, a briefing, so instantly we can mobilise the whole Quaker community in that case'.

Another way of putting this is to say that to be adequately understood the anti-war and peace movements need to be situated in a wider frame than media. The priority of influencing policy by mobilising opposition is one major dimension of this. Others include campaigning during a period of involvement of US and British military forces in an unpopular war in Iraq, apprehension about international terrorism, concerns about and within Muslim communities regarding Islamism, and the distinguishing characteristics of the groups that make up the anti-war and peace movements. 
In arguing for contextualisation, we emphasise two particular matters. One of these would be the limits of the virtual when it comes to understanding the anti-war and peace movements; the other concerns particularities of the British anti-war and peace movements.

\section{Limits of the Virtual}

For all the talk about living a mediated existence, of virtual relationships increasing in importance, we need to remember that people also live in situated places and interact, for the most part, face to face with human beings. Their outlooks are not merely formed by virtuality, but also by matters such as biographies, experiences and political circumstances. The significance of this for the anti-war and peace movements in Britain are that, despite their widespread adoption of new media, one is struck by the ways in which places and people root the movements and shape their actions (Taylor 2007). We may exemplify this with a series of examples:

1. It is striking that the anti-war and peace movements, while they utilises the internet to draw upon transglobal informational sources in putting together their web sites and assorted documents, remains emphatically oriented towards the national, and even more local, scenes (Gillan 2007). Thus while Robin Beste starts the day by scanning sites around the world to update Stop the War Coalition's web site, he stresses that StWC is 'a campaigning organisation' and that this necessarily means materials are oriented to mobilisation of members for demonstrations and protests of one sort or another. Politics remain predominately nationally organised, so campaigners need to focus where they have maximum effect. Kate Hudson, chair of the Campaign for Nuclear Disarmament, observes that 'in Britain, working on a national level, it doesn't fundamentally change anything, the internet stuff... communication on certain things can be much easier, and the access of everything is quicker. But I don't personally think it fundamentally changes how we do things politically, because the most crucial thing is forging alliances with different organisations and the kind of political approach ... it doesn't fundamentally change the way in which we work or our political approach to things'. This is a salutary reminder to those who imagine the anti-war and peace movements to be a global phenomenon.

2. Robin Beste constructs the StWC web site with the needs of local activists to the fore. He is conscious that activists need timely and pertinent materials to argue and debate with members of the public. This priority means that, however interesting the articles he finds on his daily trawl, many are rejected because they do not fit with 'giving them (activists) 
the information that they need ....in terms of how they're involved in the campaign that we're organising'. This also explains how and why Milan Rai of Justice Not Vengeance creates its widely circulated briefing papers: 'The purpose of the briefing is to give an anti-war activist a set of credible sources with which to argue against current propaganda, both face-to-face with people who they are living with, working with and so on, or if they campaigning in the street, and also if they're writing matters or writing articles and so on. ... It's supposed to be something that you have on a stall and you could give to someone who is a bit skeptical about what you're saying'.

3. Another factor that fixes anti-war and peace organisations in the locale is their membership base. The degrees of internationalism vary between organisations, with a disparate, middle class and internationally-networked group like Women in Black towards one end of the spectrum and decidedly local anti-war groups in a city such as Leicester at the other. However, even an international organisation such as the Society of Friends, with offices on mainland Europe as well as Britain and the USA, was pulled by the local concerns of their membership base which is chiefly in the USA and UK.

4. There may also be a part played here by disposition, as explained to us by Martina Weitsch who works in Brussels for the Quaker Council of European Affairs. Though there were links with North America, she said that 'in terms of coordination, there isn't any because ... most Quakers see themselves as individuals who happen to come together as a group'. There is a strong ethos in Quaker doctrine of personal responsibility, of bearing witness, and following one's conscience. Associated with it is a preference for personal meetings, something one officer at Friends House in the Euston Road explained as Quakers being 'much more about getting together as people. ...They don't sit in front of the computer, they'd much rather go out and meet people and talk to people. I don't even think five years from now that will have changed a lot. I think probably there will still be that sense of let's get together, physically, and talk about this; why would you do this in cyberspace when you could actually go down the road and see these people?'

5. When one considers the Muslim role in the anti-war movements then the question of the location of actors seems especially important. In Leicester, the Muslim population of approximately 30,000 (dominated by those from an Indian background, but also of Pakistan, Bangladesh, and Somali descent) and their 22 Mosques are concentrated to the north east of the city, specifically the areas of Highfields and Evington. The majority of Muslims in Leicester are Sunnis (Leicester Council of Faiths, 2002). In such circumstances it is not surprising that anti-war activists, living close by one another and 
with the Mosque as a frequent common meeting point, appear to have little need for internet technologies. The fact of living proximately means people interact interpersonally rather than virtually.

6. With regard to Muslim participation the anti-war movements it might also be observed that the local mosque and Imams play a key role in organising and motivating. Friday prayers, we were repeatedly told, were crucial in mobilisation of protesters. For instance, Chris Goodwin of the Leicester Campaign to Stop the War said that when her group tried to organise events involving Muslims, then it seemed it happened only when the Muslim leaders gave approval. Appreciation of the engagement of Muslims in anti-war activism has to be aware of the importance of these local, yet faith-based, factors that can be telling.

\section{Uneasy Alliances}

The anti-war and peace movements in Britain are often perceived as unified. In truth, the anti-war and peace movements are an uneasy alliance of remarkably diverse groups and individuals. It ranges along several continuums from pacifism to opposition specifically to the American invasion of Iraq, from civil libertarians to anti-imperialists who encourage the defeat of America by Iraqi 'insurgents', from the religiously motivated to the entirely secular, from direct action advocates to those committed to the power of persuasion, from the extra-parliamentary left to peers of the realm, and from right wing fundamentalists, through centrist Liberal Democrats to anarchists (Pickerill and Webster 2006).

While the original Campaign for Nuclear Disarmament (CND) developed in different circumstances, and took as its goal opposition to nuclear weapons, it also aimed to convert the Labour Party to its policy (Parkin 1968). Today the decline of class politics and of organised labour, plus the fact that it is a Labour Party premier who has played a leading role in the Iraq invasion, means that the present anti-war and peace movements are not only considerably more diverse than its predecessors but also somewhat jaundiced about established political parties. There are lobbies of Parliament, of course, but the anti-war and peace movements have an extraParliamentary focus that its predecessors lacked. It is a social movement joined together only by the common concern to oppose the 'war on terror' and pursuit of this goal operates outside party political aegis. 
In key respects it is a union of opposites. Feminists march with determinedly patriarchal Muslim elders; orthodox Muslim women wearing hijabs and not infrequently burqas campaign alongside bejeaned students; Jews for Justice marched on August $5^{\text {th }} 2006$ in London with those who held placards calling for 'Victory to the Resistance' in Lebanon and proclaiming that 'We are all Hezbollah'; and middle aged members of Women in Black quietly walk for peace alongside those, who angrily shout 'George Bush: Terrorist'. Many commentators have made much of these contradictory alliances that are found (Horowitz 2004), Gita Sahgal of Women Against Fundamentalists (2006), for instance, contending that some of the Muslim groups are connected with terrorism and neo-fascist organisations in South East Asia, a view contested by many of the Muslim groups (Ware 2005; 2006; Bright 2005).

Despite new media allowing the anti-war and peace movements to switch adeptly their campaigning agendas to include the most topical of issues such as the more recent threats of attack on Iran by American or Israeli forces, it is difficult to envisage the movements remaining united. To be sure, pacifist groups such as the Quakers and anti-nuclear activists like CND will continue, driven by their focus and faith, but the presently most significant formation, Stop the War Coalition, must encompass extraordinarily contradictory constituencies. StWC was driven from the outset by an established Marxist group, the Socialist Workers Party (SWP), which was unprepared for the large ethnic minority involvement. Lindsey German, the convenor of StWC and an SWP stalwart, recalled that in late 2001 the SWP had called a meeting to consider the invasion of Afghanistan, and found that 'loads of Muslims came and we didn't know a single Muslim at the time politically'. She describes how people such as her developed relations with Muslim groups: 'the Muslim community really surprised us because we knew nothing about it, and then one of the people who ... was of Muslim background himself, he said "look we should go to the mosques when we were building the demonstration because we knew the first demonstration was about Afghanistan". So we went to the London Mosque'.

However, a price of the coalition has been that the SWP has muted its ideological adherence to socialism and secularism. The web site of the SWP (2007) - a group once orthodoxly Leninist now insists that 'We fight alongside anybody or any organisation that wants to build the movement. The anti-war movement has gained its strength from its unity and breadth. That's why we fight to maintain the principles unity (sic) of all the coalitions and campaigns with which we are involved. We respect people with ideas that are different from ours. So, while we seek to persuade people of our revolutionary ideas, we resist moves to narrow the movement to those 
who are already part of the radical left'. Some sense of the problems this entails comes from Mike Marqusee, former StWC press officer, who told us that 'the advantage of having the SWP as a national organisation with a ... printing press and twenty full time workers and a rapid network for the distribution of leaflets... was huge in getting the Stop the War Coalition off the ground. ...And I think they were right, in the sense that they felt that this is a crossroads in global politics... It was that strong sense that brought people together, and the SWP did have that. They then though took that into meaning that nothing should be allowed to confuse anybody about what was the absolute priority, which meant that the arguments, complex arguments about secularism and religion were not heard. ... So, for example, pretty early on, those people who... questioned the link with MAB (Muslim Association of Britain) were castigated as Islamophobes'. Such tensions are likely ultimately to pull StWC apart.

\section{Conclusion}

We began this article by emphasising that people are safer than their predecessors, yet have experience of war and the threat of war through media that is unprecedented in its intensity and range. This must contribute to high levels of anxiety and fear of war recorded in opinion surveys. However, the information environment of which this mediation is composed is shifting, complex and diverse, making adherence to the influential control paradigm in media analysis problematic. Here the anti-war and peace movements find significant space for messages and has even been able to establish elements of an alternative information environment using listserves, web sites and related technologies.

However, it would be an egregious mistake to conceive war and its opponents in the anti-war and peace movements solely in terms of media. War is about 'hearts and minds', but it is also about inflicting material damage on people and places. By the same token, anti-war and peace activism is about more than persuasion. When we come to examine the anti-war and peace movements, we have stressed the need to appreciate the wider contexts within which they operate. In particular, we drew attention to the importance of acknowledging that people live in particular places and within particular relationships. This shapes how they organise, respond and campaign against war. Remembering this we may better understand that the anti-war and peace movements in the UK are decidedly national in its focus, that a priority is mobilisation to change policy, and that local relationships can be telling. Finally, we drew attention to the diversity and even contradictions found within the anti-war and peace movements. It is a broad coalition united only in that it opposes war. 


\section{References}

Bennett, W.L. (2003), 'Communicating Global Activism: Strengths and Vulnerabilities of Networked Politics', Information, Communication and Society 6(2): 143-68

Blair, Tony (2007), Our Nation's Future - Defence 12 January, available at http://www/number10.gov.uk/output/Page0735.asp

Bright, Martin (2005), 'Radical links of UK's “moderate” Muslim group', Observer, 14 August, p. 8

Calhoun, Craig (2004), 'Information Technology and the International Public Sphere', pp.1-28 in Douglas Schuler and Peter Day (eds), Shaping the Network Society Cambridge, MA: MIT Press

Castells, Manuel (1998), The Power of Identity Oxford: Blackwell

Chadwick, Andrew (2006), Internet Politics: States, Citizens and New Communication

Technologies Oxford: Oxford University Press

Coleman, Stephen (2005),'Blogs and the New Politics of Listening', Political Quarterly, pp.27380

Department of Defense (2003) Information Operations Roadmap Washington DC: Pentagon Giddens, Anthony (1994), 'Brave New World: The New Context of Politics', pp.21-38 in David Miliband (ed), Reinventing the Left Cambridge: Polity

Gillan, Kevin (2007), 'The UK Anti-War Movement Online: Uses and Limitations of Internet Technologies for Contemporary Activism' (mimeo)

Hobsbawm, E.J. (1994), Age of Extremes: The Short Twentieth Century London: Michael Joseph Horowitz, David (2004), Unholy Alliance: Radical Islam and the American Left Washington: Regnery

Human Security Report 2005: War and Peace in the 21 ${ }^{\text {st }}$ Century (2006). New York: Oxford University Press. Available at http://www.humansecurityreport.info/ Ignatieff, Michael (2000), Virtual War: Kosovo and Beyond London: Chatto and Windus Leicester Council of Faiths (2002) An Overview of the Major Faiths in the City of Leicester, issue 4, www.leicestercounciloffaiths.org.uk Lenhart, Amanda and Fox, Susannah (2006), Bloggers: A Portrait of the Internet's New Storytellers Washington: PEW Internet and American Life Project Mazower, Mark (1998), Dark Continent: Europe's Twentieth Century Harmondsworth: Penguin McNair, Brian (2006), Cultural Chaos: Journalism, News and Power in a Globalised World London: Routledge 
Mueller, John (2004), The Remnants of War (Cornell Studies in Security Affairs). Ithaca: Cornell University Press

Parkin, Frank (1968), Middle Class Radicals Manchester: Manchester University Press

Pax, Salam (2003), The Baghdad Blog London: Guardian Books

Pickerill, J. and Webster, F. (2006), 'The Anti-War/Peace Movement in Britain and the

Conditions of Information War', International Relations 20 (4): 407-423

Pickerill, Jenny (2003), Cyberprotest: Environmental Activism Online Manchester: Manchester University Press

Riverbend (2005), Baghdad Burning: Girl Blog from Iraq London: Marion Boyars

Rumsfeld, Donald (2006), Speech to Council on Foreign Relations, February 17.

Seaton, Jean (2005), Carnage and the Media: The Making and Breaking of News and Violence

London: Allen Lane

SWP [Socialist Workers Party] (2007), http://www.swp.org.uk/about.php Accessed 20 January $\underline{2007}$

Taylor, Ian (2007), ‘Thinking local, acting global', Peace News At

http://www.peacenews.info/issues/2480-81/248006.html Accessed 2 February 2007

Taylor, Phillip M. (2002), War and the Media: Propaganda and Persuasion in the Gulf War

Manchester: Manchester University Press

Tumber, H. and Webster, F (2007), 'Globalization and Information and Communications

Technologies: The Case of War', in George Ritzer (ed), Blackwell Companion to Globalization Maldon, MA: Blackwell

Tumber, H. and Webster, F. (2006), Journalists under Fire: Information War and Journalistic

Practices London: Sage

Tyler, Patrick (2003), 'A New Power in the Streets', New York Times, 17 February.

Ware, John (2005), 'On Muslim Council of Britain', BBC Today, Radio 4. Transcript at http://newsvote.bbc.co.uk/mpapps/pagetools/print/news.bbc.co.uk/

Ware, John (2006), 'Faith, hate and Charity', BBC Panorama, 3 August. Transcript at http//news.bbc.co.uk/1/hi/programmes/Panorama/523486.stm

Women Against Fundamentalists (2006), Hecklers, BBC Radio 4, 23 August. Available at http://www.bbc.co.uk/radio4/hecklers/pip/ixhsj 